\title{
ANALYSIS OF THE NEEDS OF CHILDREN WITH SPECIAL NEEDS (TUNAGRAHITA) IN PHYSICAL EDUCATION LEARNING AT SD LEVEL IN SKH PANDEGLANG
}

\section{Devaron Suardi ${ }^{1 *}$, Idris Supriadi ${ }^{2}$}

${ }^{12}$ Department of Sports Education, STKIP Syekh Manshur, Pandeglang, Indonesia

\begin{tabular}{l} 
Article Info \\
\hline Article History: \\
Received September 2020 \\
Revised September 2020 \\
Accepted September 2020 \\
Available online September 2020 \\
\hline Keywords: \\
Analysis, Physical Education, \\
Children with special needs \\
\hline
\end{tabular}

\begin{abstract}
The purpose of this research is to analyze the needs in the learning process of children with special needs in physical education learning. The method used in this research is descriptive qualitative method using data triangulation techniques, namely the series of observations, documentation and interviews. The subjects in this study were peserda basic level points at SKh 1 Pembina Pandeglang. This research reveals the needs needed in the learning of children with special needs. These needs are 1) Synchronizing understanding of the learning objectives of physical education for the elementary school level. 2) Better understand the personality of students 3) Conduct a comprehensive approach to students 4) Modify suggestions according to the needs in the learning process while still prioritizing the level of safety for students. Systematic and structured physical education learning will have a positive impact on the basic movement skills of students in general. By improving the skills of participants or children with special needs, it has indirectly provided encouragement and confidence for children with special needs to socialize and feel recognized by the surrounding community. Systematic and structured physical education learning will have a positive impact on the basic movement skills of students in general. By improving the skills of participants or children with special needs, it indirectly gives encouragement and confidence to children with special needs to get along and feel recognized by the surrounding community. Systematic and structured physical education learning will have a positive impact on the basic movement skills of students in general. By improving the skills of participants or children with special needs, it indirectly gives encouragement and confidence to children with special needs to get along and feel recognized by the surrounding community.
\end{abstract}

Corresponding address : Pandeglang, Banten, Indonesia

Email
: devaronsuardi@gmail.com
ISSN 2685-6514 (online)

ISSN 2477-331X (print)

DOI: $10.33369 / j k . v 4 i 2.12601$ 


\section{INTRODUCTION}

The need for learning physical education, sports and health includes all aspects contained therein, starting from the competence of teachers who have received special training to handle mentally retarded participants, adapted learning models and methods, sports and health facilities and infrastructure including big balls, small balls , hulahup, cone, field, basket and others. Physical education is an educational process through physical or physical activity and at the same time is an educational process to improve overall movement skills.Education is a conscious and planned effort to create an atmosphere of learning and the learning process so that students actively develop their potential to have religious spiritual strength, selfcontrol, personality, intelligence, noble character, and skills needed by themselves, society, the nation and the State. 11 (Gumawang, 2020: 11) However, physical education learning does not rule out affective and cognitive aspects of learning.

Education is an effort to help children's development so that they are more progressive in their academic development and social emotions so that they can live in their surroundings (Apriyanto, 2012: 5).All aspects can be collaborated in one lesson that requires children to move properly and correctly accompanied by mutual respect, respect and uphold the value of sportsmanship in it. The need in the learning process of students for learning physical education, sports and health according to the existing classification will get different results with almost the same treatment, understanding the behavior that occurs in the field will be analyzed in order to get the right method in implementing education in special schools, especially in mentally retarded class. Physical education for children with special needs or in other terms, namely adaptive physical education, is physical education that has been modified to meet the needs of children with disabilities (Mulyono, 2009: 145). Mentally retarded is one of the many disabilities, and the terrible treatment for mental retardation is different from other disabilities. Because in general mental retardation is a disability based on mental retardation.In order to meet the movement needs of children with mild mental retardation, special learning should be carried out which can stimulate the basic movement abilities of children with mild mental retardation, as well as the ability (Ardiansyah and Tuasikal, 2016: 178)

Physical education learning generally focuses on learning in the aspects of motion which aims to improve the overall quality of movement of students. For this reason, special skills are needed in dealing with students who experience mental retardation, such as patterns, models and specially designed learning styles.

A mentally retarded child or in other terms referred to as mental retardation is a child who has very low intelligence, so researching developmental tasks requires special education and guidance services (Efendi, 
2006: 110).Normal children can learn fundamental skills instinctively while playing, while mentally retarded children need to be specially trained, including the use of methods that are in accordance with the characteristics of their disabilities (Soemantri, 2007: 110).With a level of intelligence that is below average, it makes it difficult for the child to do normal learning, special skills and methods are needed so that learning can be achieved. The development of mental retardation as a whole experiences obstacles not only from intelligence but also includes aspects of motor, behavior, interaction, and communication.Students with mental retardation need an activity to optimize their body condition so that their health is maintained. One of the activities that can optimize a healthy body condition is by actively moving. (Pangesti and Sudarsini, 2015: 5)

Delay or intelligence below average is a very big problem in carrying out normal learning. This basic movement is very important in supporting the ability of activities of daily living independently (Utari and Indahwati, 2015: 280)

The development of mental retardation as a whole experiences obstacles not only from intelligence but also includes aspects of motor, behavior, interaction, and communication. Delay or intelligence below average is a very big problem in carrying out normal learning. For mentally disabled children, special treatment, teachers, methods, facilities and infrastructure are needed to achieve learning objectives. Tuna grahita can be classified into 3 groups.

1. Mild intellectual disability

Mild mental retardation is also called maroon or debil, with an IQ of 68-52 according to Binet, an IQ of 69-55 according to the Weschler scale.

2. Moderate mental retardation

Moderate mental retardation is also known as Imbesil, with an IQ ranging from 51-36 on the Binet scale, and 50-40 on the Weschler scale.

3. Severe mental retardation

Severe mental retardation is often called an idiot. It can be divided into two, namely severe mental retardation (Severe) with an IQ range of 32-20 on the Binet scale, and 3925 on the Weschler scale. and very severe mental retardation with an IQ below 10 on the Binet scale and an IQ below 24 on the Weschler scale. (Astati, 1995: 106).

Mentally retarded children are children who experience developmental disorders, in their thinking power and their entire personality so that they are unable to live on their own strength in society even though they live a simple way (Mumpuniarti, 2007: 5-6). Classification according to the level of disability makes it imperative to differentiate. Physical education learning levels and methods, with models, teaching styles, learning patterns, and facilities and infrastructure that support and do not endanger students.Playing is a way to explore and experiment with the world around them so that children 
will determine something from their playing experience (Syahrudin, et al. 116)

Games in learning do not mean that they will eliminate seriousness, ignore elements of discipline, and eliminate the substance of subject matter in accordance with the curriculum. Learning materials containing a set of game forms will enrich movement and arouse passion in its implementation (Yumaika and Ardisal 2020: 117).

Physical education for mentally retarded children requires a special design so that their motor skills experience optimal growth and development (Louk and Pamuji 2016: 25). By selecting the right method and taking into account the level of safety of adequate facilities, physical education learning in special schools will run well.

\section{METHODS}

This research is a qualitative research with analytical descriptive method. Data collection techniques are divided into documentation, observation and interviews. The research variables analyzed were the needs in the learning process and the behavior of the subject. According to Sugiyono (2012: 308), data collection techniques are the main thing in research because the main purpose of research is to get data. Data collection techniques consisted of observation, interviews and documentation.

According to Purwanto (2010: 177) descriptive research is research that only involves one variable in one group, without connecting with other variables or comparing with other groups.

\section{Participants}

Participants or subjects in this study were 27 students spread across 6 levels from grade 1 to 6 in $\mathrm{SKh}$ Pandeglang Regency, which consisted of students with several different characteristics, such as qualifications or levels of mental retardation from moderate mental retardation to the qualification of Down syndrome. . Participants in this study were the principal, teachers and students. This is the basis for understanding the basic needs of SKh, because data with accuracy and data collection on a broader basis will get maximum results in narrowing down later conclusions.

\section{Sampling Procedures}

Subjects or samples used in data collection or collection are all elementary level students. Collecting data from students can only be done through direct observation and review in Physical Education learning, it is very difficult to conduct interviews with students because it is very difficult to conduct interviews with students because it is difficult to conduct interviews and get information by conducting questions and answers. Students have difficulty understanding the questions given and providing answers. which supports the progress of data.

Interviews related to the need for learning would be more effective for teacher educators and school principals 
at SKh Pembina Pandeglang. Because we can get detailed data about learning and the needs in implementing learning. The total sample size was 27 students, 6 homeroom teachers, and 1 school principal.

Observation or data collection of students is carried out during physical education lessons at school directly. It aims to observe what happens in the learning process, both the constraints that arise due to various characteristics, and the solutions taken by the teacher so that learning achieves the desired goals. After taking the data directly, the researcher takes documentation which aims to strengthen the data that will be summarized at the time of the research, and the last is to conduct interviews with several teachers related to physical education learning as a whole. Whether it's from the obstacles that often occur, the solutions to be applied, and what needs have not been met in the physical education learning process.

If the data has been obtained in its entirety, it will be processed in accordance with existing conditions or real conditions that occur in the field. By describing the suitability of the observations, documentation and interviews carried out.

\section{Materials and Apparatus}

The materials used in this study consist of consumables and nonconsumable materials. For example, consumables are pens, paperand paper to record and all findings that occur in the field. With relatively many students who have different characteristics for each individual researcher requires several assistants for data collection, this aims to increase the level of accuracy or accuracy of the data collected.

Non-consumable materials such as equipment that can be used repeatedly, such as stopwatches, cameras, smartphones, sports equipment whistles (large balls, small balls, balloons, cones, baskets, etc.). The infrastructure or the field uses the available field at SKh Pembina Pandeglang.

\section{Procedures}

In this study, there were several steps that were taken by researchers to obtain data as accurate as possible. The first way was to make observations, namely visiting the Pandegalang Advisory Committee to find out more detailed conditions in the physical education learning process. In the observation stage, researchers and research assistants try to study the physical education learning process carried out at SKh. The second is documentation of physical education learning by taking some videos and photos, using a camera and smartphone.

Meanwhile, the latter was conducting interviews with the principal and several homeroom teachers to strengthen the data that had been collected. And the final stage is to unify and match all the data obtained by using the triangulation research method which is described descriptively in accordance with what happened in the field, and if there are several statements that are deviant or that are not suitable between events in the field and statements from 
the results of interviews from the homeroom teacher and headmaster.

\section{Design or Data Analysis}

This research is a qualitative research with analytical descriptive method. Data collection techniques are divided into documentation, observation and interviews. The research variables analyzed were the needs in the learning process of the subject in carrying out the learning process. Data collection techniques are the main thing to carry out research because the purpose of research is to obtain data that will be processed according to the method to be used. The data collection techniques consisted of observation, documentation and interviews.

\section{RESULT}

The results of observations made on Physical Education learning at SKh Pembina Pandeglang by directly observing the learning process and direct interviews, the researchers found the following findings: 1) In the learning process students are often confused when given instructions in learning. 2) Students are often still engrossed in their own activities and slightly ignore instructions from educators. 3) There are also several cases where students are happy or very enthusiastic in carrying out activities and want to carry out activities continuously even though the series of movements instructed are not in accordance with what they are doing. 4) There are students who are more likely to be silent and slightly neglect learning, for this the educator tries to invite and move the body of students so that students can carry out learning activities. 5) In the learning process, educators always try to involve students in carrying out the learning process that has been implemented. 6) There are cases where students do not want to carry out the learning process with the theme of running obstacles, a student does not want to take part in the activity, after being traced that the student does not want to follow because at that time the student wants to play catch and catch ball. 7) Educators have given two different learning themes in one class, this is because there are several students using different tools from the tools provided by the educator. 8) Often there are additional students from other classes this is because each mentally disabled child has different interests according to his wishes at that time (depending on the mood) so that the initial students who attend sports hours are 3 to 4 people then it is slow. Gradually it will increase and can even reach 10 people or more. 9) The curriculum used in learning is the 2013 DIKSUS (Special Education) curriculum, this curriculum is slightly modified according to existing needs and occurs in the field. The modified curriculum also aims to increase students' confidence in carrying out an activity, and maybe this will take quite a long time compared to normal classes. 10) means of learning are the most vital in the learning process. The facilities used are still very few which have been modified, according to the recognition of the principal of the learning school by using modified facilities according to the needs and safety of students. 11) The 
school has a little difficulty because it is highly expected that physical education learning will really be handled by teachers with a background from physical education, because until now physical learning at SKh is on average still held or handled by the homeroom teacher. Because in general the homeroom teacher understands more about the learning process for children with special needs, but to increase movement activities in a structured and systematic manner according to age development and ability is still not handled appropriately because no teacher has a physical education background.

\section{DISCUSSION}

There are still many things that need to be studied in learning sports education for schools with special needs (SKh) such as actions taken during learning, choosing the right facilities, understanding the behavior and character of participants, and being able to increase participants' interest in learning, and improve student achievement. to participate in events that have been regularly held both at the national and international levels.

Patience is required to carry out learning and to improve the quality of movement or performance of the mentally disabled. Because in terms of learning, participants tend to need various kinds of encouragement or motivation. Various sources are needed, and further research is needed to improve physical education learning at SKh so that learning objectives and perspectives can be achieved according to what is stated.

\section{CONCLUSION}

The conclusion from the research on the analysis of the needs of children with special needs (mental retardation) in physical education learning at the elementary school level at SKh in Pandeglang is how an educator can meet the needs of children with special needs (mental retardation) in carrying out learning in accordance with what the main needs of the participants are. students. Class teachers at SKh have better experience in class management and special handling of students, but there are still many who do not understand the true goals of physical education while physical education teachers generally have experience in physical education learning but still feel awkward and have difficulty facing children those with special needs in the learning process.

\section{ACKNOWLEDGEMENT}

Praise be to Allah SWT for giving researchers the opportunity to carry out this research from beginning to end. Thank you or prayers from the parents of Father (Suardi) and Mother (Asmawati) and wife (Ira Asyura) who have given prayers and encouragement to carry out research. Furthermore, the Research and Development Agency of the Ministry of Home Affairs has provided Research Grants for Beginner Lecturers to researchers to improve research results and knowledge in the field of physical education. 


\section{REFERENCES}

Abdurrahman, Mulyono. (2009). Pendidikan Bagi Anak Kesulitan Belajar. Jakarta : Rineka Cipta. Hlm. 145

Apriyanto, Nunung. 2012. Seluk- Beluk Tunagrahita dan Strategi Pembelajarannya. Jogjakarta: Javalitera Delphie, B. 2007. Pembelajaran Anak Tunagrahita. Bandung : PT Refika Aditama. Hlm. 5

Ardiansyah, Wahyu., Tuasikal, Abdul Racman Syam. 2016 Modifikasi Permainan Lari Estafet Untuk Meningkatkan Gerak Dasar Manipulatif Anak Tunagrahita Ringan. Jurnal Pendidikan Olahraga dan Kesehatan. 4 (1). Hlm. 177-184

Astati. (1995). Karakteristik Anak Tunagrahita. Jakarta. Hlm. 106

Effendi, Mohammad. (2006). Pengantar Psikopedagogik Anak Berkelainan. Jakarta : Bumi Aksara. Hlm. 110

Gumawang, Dirham. (2020) Indeks Inklusi Skh Negeri 01 Pembina Pandeglang Sebagai Role Model Implementasi Pendidikan Inklusif. Jurnal Ilmiah Nasional RAUSYAN FIKR, 1 (3), Hlm. 11-19

Laok, Michael Johanes H., Pamuji Sukoco. Pengembangan Media Audio Visual Dalam Pembelajaran Keterampilanmotorik Kasar Pada Anak Tunagrahita Ringan. Jurnal Keolahragaan. 4 (1). Hlm. 24-33

Martinus, M., \& Kesumawati, S. A. (2020). PELAKSANAAN PERMAINAN GERAK DASAR MANIPULATIF PADA ANAK TUNAGRAHITA DI SDLB C KOTA PALEMBANG. Kinestetik: Jurnal Ilmiah Pendidikan Jasmani, 4(1), 117-121.

Mumpuniarti. (2007). Pendekatan Pembelajaran Bagi Anak Hambatan Mental. Yogyakarta : Kanawa Publisher. Hlm. 5-6

Pangesti, Restu., Sudarsini. 2015. Pengembangan Media Video Senam Irama Dalam Pembelajaran Pendidikan Jasmani Adaptif Pada Siswa Tunagrahita. Jurnal Penelitian
Dan Pengembangan Pendidikan Luar Biasa. 2 (1). Hlm. 5-9

Purwanto. 2010. Metodologi Penelitian Kuantitatif Untuk Psikologi dan Pendidikan. Yogyakarta: Pustaka Pelajar. Hlm. 177

Soemantri, T. Sutjihati. 2007. Psikologi Anak Luar Biasa. Bandung: PT Refika Aditama. Hlm. 110

Sugiyono. 2012. Metode Penelitian Pendidikan: Pendekatan Kuantitatif, Kualitatif, dan R\&D. Bandung : Alfabeta . Hlm. 308

Syahruddin, Syahruddin, Muhammad Peningkatan Koordinasi Mata Tangan Melalui Model Pembelajaran Berbasis Bermain Bagi Anak Tuna Grahita. Seminar Nasional LP2M UNM. 2 (1). 116-119.

Utari, Yuniar Indah., nanik Indahwati. 2015. Upaya Meningkatkan Gerak Dasar Lokomotor Anak Tunagrahita Ringan Melalui Permainan Tradisional. Jurnal Pendidikan Olahraga dan Kesehatan 3 (2). Hlm. 279-282

Yumaika, Cicha,. Ardisal. Efektivitas Senam Ceria Untuk Meningkatkan Kemampuan Motorik Kasar Anak Tunagrahita Ringan. Ranah Research : Journal of Multidicsiplinary Research and Development. 2(3). HIm. 46-52 